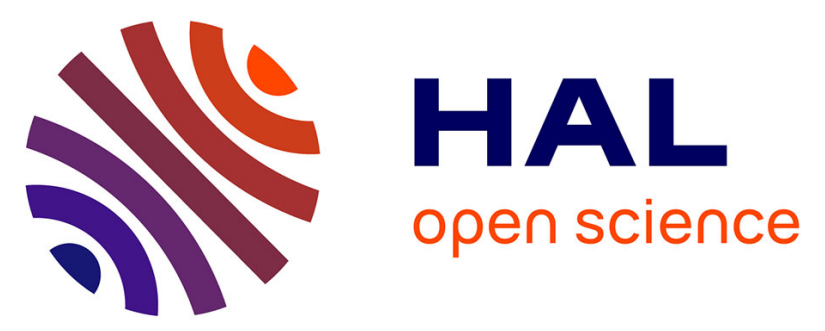

\title{
Genetic characterization of G3 rotaviruses detected in Italian children in the years 1993-2005
}

Simona de Grazia, Vito Martella, Claudia Colomba, Antonio Cascio, Serenella Arista, Giovanni Maurizio Giammanco

\section{- To cite this version:}

Simona de Grazia, Vito Martella, Claudia Colomba, Antonio Cascio, Serenella Arista, et al.. Genetic characterization of G3 rotaviruses detected in Italian children in the years 1993-2005. Journal of Medical Virology, 2009, 81 (12), pp.2089. 10.1002/jmv.21615 . hal-00531824

\section{HAL Id: hal-00531824 \\ https://hal.science/hal-00531824}

Submitted on 4 Nov 2010

HAL is a multi-disciplinary open access archive for the deposit and dissemination of scientific research documents, whether they are published or not. The documents may come from teaching and research institutions in France or abroad, or from public or private research centers.
L'archive ouverte pluridisciplinaire HAL, est destinée au dépôt et à la diffusion de documents scientifiques de niveau recherche, publiés ou non, émanant des établissements d'enseignement et de recherche français ou étrangers, des laboratoires publics ou privés. 


\section{Journal of Medical Virology}

WILEY

\section{Genetic characterization of $\mathbf{G} 3$ rotaviruses detected in Italian children in the years 1993-2005}

\begin{tabular}{|r|l|}
\hline Journal: & Journal of Medical Virology \\
\hline Wanuscript ID: & JMV-09-1264.R2 \\
\hline Diley - Manuscript type: & Research Article \\
\hline Author: & 26 -Jun-2009 \\
\hline Complete List of Authors: & $\begin{array}{l}\text { De Grazia, Simona; University of Palermo, Department of Health } \\
\text { Promotion Sciences } \\
\text { Martella, Vito; University of Bari, Public Health and Animal } \\
\text { Sciences; University of Bari, Public Health and Animal Sciences } \\
\text { Colomba, Claudia; University of Palermo, Department of Health } \\
\text { Promotion Sciences } \\
\text { Cascio, Antonio; University of Messina, Clinica delle Malattie } \\
\text { Infettive } \\
\text { Arista, Serenella; University of Palermo, Department of Health } \\
\text { Promotion Sciences } \\
\text { Giammanco, Giovanni; University of Palermo, Department of Health } \\
\text { Promotion Sciences }\end{array}$ \\
\hline Keywords: & \begin{tabular}{l} 
rotavirus G3P[8], sequence analysis, NSP4, gastroenteritis, Italy \\
\hline
\end{tabular} \\
\hline
\end{tabular}

\section{今 ScholarONE" \\ Manuscript Central}




\section{Figure 1}

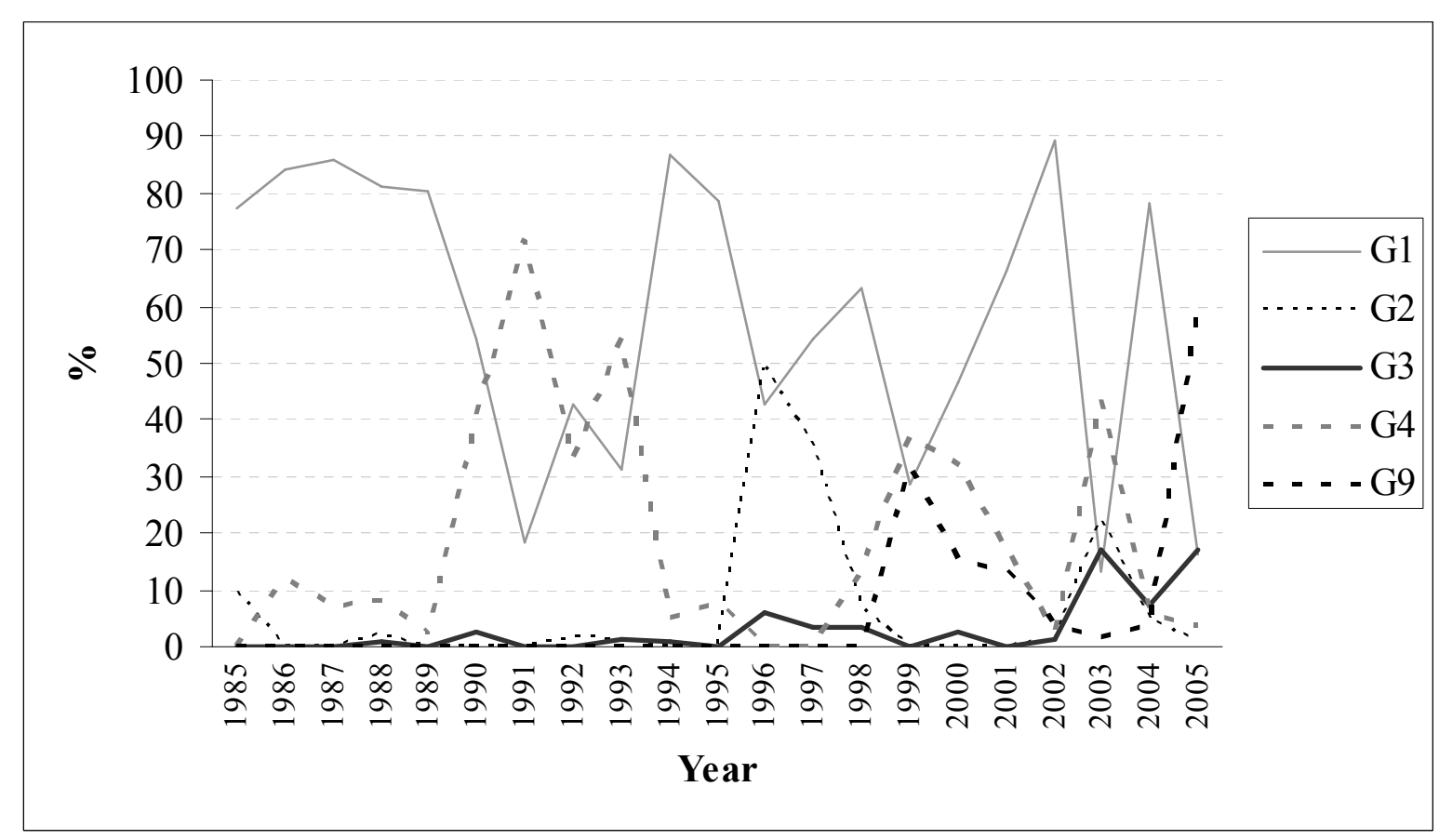

John Wiley \& Sons 
Figure 2. Phylogenetic analysis of nucleotide sequences of the VP7 gene of G3 strains. Italian $\mathrm{G} 3 \mathrm{P}[8]$ strains are highlighted in boxes, G3P[9] and G3P[3] are in bold. The origin of rotavirus strains is indicated as follows: hu=human; $\mathrm{ca}=$ canine. The tree was generated based on the neighbor-joining method using ClustalW program. Bootstrap values above $50 \%$, estimated with 1,000 pseudoreplicate data sets, are indicated at each node. $190 \times 275 \mathrm{~mm}$ (96 x 96 DPI) 
Figure 3. Deduced amino acid sequences of the NSP4 protein of Italian G3P[8] strains collected during the study period. The region involved in the binding to VP5* (aa 114-147) is indicated in light grey. The VP6-binding region (aa 156-175) is marked in dark gray. The interspecies variable domain (aa 131-141) is indicated by the thick dotted area. The sequence of the enterotoxic peptide (aa 114-135) corresponds to the thin dotted area. Critical residues for antibodies recognition are highlighted $(\boldsymbol{\nabla})$. Conserved amino acid residues are indicated by dots. Wa/hu/G1P[8] is included as the NSP4 genotype E1 rotavirus standard. $275 \times 190 \mathrm{~mm}(96 \times 96 \mathrm{DPI})$ 


\section{Genetic characterization of $\mathbf{G 3}$ rotaviruses detected in Italian children in the} 2 years 1993-2005.

$3{ }^{1}$ Simona De Grazia, ${ }^{2}$ Vito Martella, ${ }^{3}$ Claudia Colomba, ${ }^{4}$ Antonio Cascio, ${ }^{1}$ Serenella Arista, $4 \quad{ }^{1 *}$ Giovanni M. Giammanco

5

6 Dipartimento di Scienze per la Promozione della Salute "G. D' Alessandro", Sezione di

7 Microbiologia ${ }^{1}$, Sezione di Malattie Infettive ${ }^{3}$, Università di Palermo;

8 Dipartimento di Sanità Pubblica e Zootecnia, Università di Bari²;

9 Clinica delle Malattie Infettive, Università di Messina ${ }^{4}$

10

11 Corresponding author: Dipartimento di Scienze per la Promozione della Salute "G. 12 D'Alessandro", via del Vespro 133, 90127, Palermo, Italia. Phone: +39 091 6553663; Fax: +39 091 13 6553676; e-mail address: g.m.giammanco@unipa.it (G.M. Giammanco).

15 Shortened title: Genotyping of Italian G3 rotaviruses 
1 Abstract

2 In recent years an apparent increase in the frequency of detection of G3P [8] rotaviruses has been 3 observed worldwide. Similarly, in Italy G3P[8] strains have been detected sporadically and in a 4 scattered fashion over 20 years, whereas in 2003 and 2005 G3P[8] rotavirus activity increased 5 markedly. By analysis of the VP7, VP4, VP6 and NSP4 genes of a selection of G3P[8] rotaviruses 6 detected between 1993 and 2005, a remarkable sequence conservation was observed in the VP7, 7 VP4 and VP6 genes. By converse, after 2002 the Italian G3P[8] strains were found to possess 8 unique mutations in significant regions of the NSP4 protein.

9 10 11 12 13 14 15 16 17 18 19 20 48 50 51 52 53 54 55 56 57 58 592 60

Keywords: rotavirus G3P[8], sequence analysis, NSP4, gastroenteritis, Italy 


\section{Introduction}

Rotaviruses are the major cause of acute gastroenteritis in children and infants worldwide,

3 being responsible for more than 600,000 deaths annually, chiefly in developing countries [Parashar

4 et al., 2006]. Rotaviruses, Reoviridae family, possess a triple-layered virion, that encloses 11 double 5 stranded (ds) RNA segments [Estes and Kapikian, 2007]. The two outer capsid proteins VP7 and

6 VP4 and the inner capsid protein VP6 are antigenically dominant and are used to classify rotavirus

7 strains into G (VP7) and P (VP4) types and to attribute the subgroup (VP6) specificity [Estes and 8 Kapikian, 2007]. To date, $22 \mathrm{G}$ and $31 \mathrm{P}$ genotypes, and $4 \mathrm{SG}$ specificities have been established in 9 human and animal group A rotaviruses [Khamrin et al., 2006; Estes and Kapikian, 2007; Schumann 10 et al., 2009; Solberg et al., 2009; Trojnar et al., 2009]. Recently, based on sequence comparison, a 11 new classification system has been proposed for all the 11 genome segments [Matthijnssens et al., 12 2008]. 35 36

Although the genes coding for VP7, VP4, and VP6 segregate independently, and numerous 14 combinations are possible theoretically, many epidemiological studies indicated that G1, G3, G4 and G9 types are commonly associated with P[8] type, SGII specificity and a "long" pattern of migration of the dsRNA segments in polyacrylamide gel electrophoresis (e-type), while G2 strains display P[4] type, SGI specificity and "short" e-type [Estes and Kapikian, 2007]. The G1P[8] rotavirus strains have been acknowledged universally as the most prevalent and ubiquitous, while the incidence of strains with G2P[4], G3P[8], G4P[8] and G9P[8] specificities may vary regionally and temporally. Other G/P combinations sporadically appear but may also acquire local relevance [Santos and Hoshino, 2005].

The non-structural protein NSP4 is a key protein involved in morphogenesis and pathogenesis of rotavirus [Estes and Kapikian, 2007]. Sequence analysis has revealed that the NSP4 gene of group A rotaviruses may be genetically classified into 11 genotypes, E1 to E11 [Matthijnssens et al., 2008], which include the five genotypes, Kun (A)-, Wa (B)-, Au-1 (C)-, EW (D)-, or avian (E)-like, described previously. Within NSP4 genotypes E1 (B) and E2 (A), species- 
1 specific patterns of segregation may be revealed by phylogenetic analysis [Ciarlet et al., 2000]. By 2 sequence analysis and PCR genotyping with specific primers, it has been shown that G1P[8], 3 G3P[8], G4P[8] and G9P[8] strains possess a NSP4 E1 (B) genotype, while G2P[4] have NSP4 E2 4 (A) genotype and G3P[9] viruses have either NSP4 E2 (A) or E3 (C) genotype [Estes and Kapikian, 5 2007; Bányai et al., 2009].

Rotavirus surveillance world-wide has shown in recent years changes in the distribution of 7 rotavirus $\mathrm{G}$ types, with decrease of G1 strains and parallel increase of G3 strains (15.8\%-63\%) in 8 Brazil, Japan, China, Russia, Ireland, Tunisia and Spain [Zhou et al., 2003; Fang et al., 2005; Lo et 9 al., 2005; Reidy et al., 2005; Sanchez-Fauquier et al., 2006; Yoshinaga et al., 2006; Chouikha et al., 10 2007; Phan et al., 2007]. G3 rotaviruses infect almost all animal species and interspecies 11 transmission and/or reassortment with animal rotaviruses accounts likely for the detection of human 12 G3 strains with unusual genetic/antigenic features [Khamrin et al., 2006; De Grazia et al., 2007a; 13 De Grazia et al., 2008; Tsugawa and Hoshino, 2008].

In Italy, epidemiological surveillance for rotavirus enteritis in children has been carried out uninterruptedly since 1985 in Palermo. The possibility to analyse a collection of rotavirus strains 16 spanning such a long time period has been useful for investigating the mechanisms of rotavirus 17 evolution [Arista et al., 2006]. In this study, a selection of G3 strains identified over a long temporal 18 range was analysed by comparing the genes coding for the outer capsid proteins VP7 and VP4, the 19 inner capsid protein VP6 and the non-structural protein NSP4. 


\section{$1 \quad$ Materials and Methods}

2 Samples. In the period 1985-2006, 1591 rotavirus-positive samples were obtained from children of 3 less than 5 years of age, hospitalized with acute gastroenteritis at the "G. Di Cristina" Children's 4 Hospital of Palermo. Fifteen of the 53 strains exhibiting a G3P[8] type were selected for this study 5 on the basis of the year of isolation, of the availability of faecal samples, and of RNA conservation, 6 as revealed by RT-PCR performed with multiple sets of specific primers (Table I).

Determination of serotype and subgroup. G typing was performed according to previously published methods [Arista et al., 1990], with MAbs RV4:2, RV5:3, RV3:1, and ST3-3:1, respectively, which are reactive with G1-to-G4-specific viral protein VP7 [Coulson et al., 1987].

Subgrouping was performed with subgroup I- and subgroup II specific MAbs (255/60 and 631/9)

12 reactive with viral protein VP6, as described elsewhere [Arista et al., 1990].

RNA extraction and RT-PCR. Rotavirus RNA was extracted from $10 \%$ fecal suspensions as described by Boom et al. [Boom et al., 1990]. The extracted RNA was resuspended in RNase-free sterile water and used for reverse transcription (RT)-PCR with random primers [Iturriza-Gòmara et al., 1999]. To determine the $\mathrm{G}$ and $\mathrm{P}$ genotypes, specimens were analyzed with type-specific primers by a heminested RT-PCR strategy. In a first PCR round, a 1,060-nucleotide-long fragment of the gene encoding VP7 was amplified with a generic oligonucleotide primer pair (Beg9-End9) [Gouvea et al., 1990; Iturriza-Gòmara et al., 2004], and the G types were subsequently predicted in a second PCR round with a pool of internal primers specific for the G1, G2, G3, G4, and G9 genotypes in combination with the reverse consensus primer [Gouvea et al., 1990; Iturriza-Gòmara et al., 2004]. Similarly, an 876-bp fragment of the fourth genome segment, encompassing the VP8* portion of VP4, was amplified with generic primers Con3 and Con2, and P genotyping was carried out with internal primers specific for the P[4], P[6], P[8], and P[9] genotypes [Gentsch et al., 1992; Iturriza-Gòmara et al., 2004]. The PCR mixtures were prepared and thermal cycling was performed 
1 as previously described [Iturriza-Gòmara et al., 2004]. Amplicons were analyzed by electrophoresis 2 with a 2\% SeaKem LE (Cambrex Bio Science Rockland Inc., Rockland, ME) agarose gel in Tris3 acetate-EDTA at $6 \mathrm{~V} / \mathrm{cm}$ for $60 \mathrm{~min}$. To determine the E and I genotypes, the NSP4 and VP6 genes 4 were amplified by RT-PCR as described elsewhere [Lee et al., 2000; Iturriza-Gòmara et al., 2002].

5 Sequence and phylogenetic analyses. Amplicons of the genes encoding VP4, VP6, VP7 and NSP4

6 were directly sequenced with the specific primers. The amplicons were purified with GeneClean 7 purification spin columns (Q-biogene, Cambridge, United Kingdom) prior to sequencing with the 8 CEQ2000 Dye Terminator Cycle Sequencing Quick Start Kit (Beckman-Coulter, Fullerton, CA). 9 All methods were carried out by following the manufacturers' instructions. Sequences were 10 resolved with an automated sequencer (CEQ; Beckman-Coulter). Sequence alignment was 11 performed with CLUSTAL W [Thompson et al., 1994] and phylogenetic analysis was carried out 12 with the MEGA software, version 3.0 [Kumar et al., 2004], using the Kimura's two-parameter 13 distance model of correction and the neighbor-joining method to construct the phylogenetic tree. 14 The statistical significance of the inferred phylogenies was estimated by bootstrap analysis with 151,000 pseudoreplicate data sets. The sequences were aligned with and compared to additional 16 sequences obtained from online databases. Sequence alignment and phylogenetic analyses were 17 carried out on partial VP7 (904 bp), VP4 (VP8*) (480 bp), VP6 (316 bp) and NSP4 (717 bp) 18 fragments and on the deduced amino acids (aa). 


\section{Results}

In the surveillance period 1985-2006, among the 1591 rotavirus-positive samples obtained,

$359 \mathrm{G} 3$ rotaviruses $(3.7 \%)$ were detected, with a high proportion $(53 / 59=89.8 \%$, or $3.3 \%$ of the

4 rotavirus-positive samples) of G3P[8] strains. G3 strains were detected at low prevalence (0-6.1\%)

5 until 2002, whereas in 2003 and 2005 their prevalence reached $17 \%$ and $16.9 \%$, respectively

6 (Figure 1). Fifteen of the 53 strains exhibiting a G3P[8] type were selected in order to investigate

7 their evolution (Table I). The VP7 serotype and the VP6 subgroup specificities of all of these strains

8 were initially determined with MAbs, and all of the strains exhibited G3 serotype and subgroup II

9 specificity. By sequence analyses of the VP6 gene, all the 15 G3P[8] strains were found to have a

10 genotype I1, thus confirming the antigenic characterization with MAbs (data not shown). The

11 Italian G3P[8] strains displayed $>85 \%$ nt and $93.3-100 \%$ aa identity to reference I1 strains in the

12 examined VP6 fragment. Nearly all of them tightly clustered with the reference I1 strain RMC437 13 (about 99\% nt identity), but one strain, PA49/03, clustered with the I1 strain US0408 (99\% nt 14 identity).

In the VP7 (nt 49-953)-based phylogenetic analysis (Figure 2), the Italian G3P[8] 16 rotaviruses clustered into a distinct lineage, along with the vast majority of the G3P[8] human 17 rotavirus strains, including the emerging G3 strains recently described in Japan, China, Russia, 18 Thailand and Ireland [Reidy et al., 2005; Phan et al., 2007; Trinh et al., 2007]. Almost all the human 19 Au-1-like G3P[9] strains were grouped in a distinct lineage, including also feline G3P[9] strains. 20 The Italian G3P[8] showed 97.4-99\% aa identity to G3P[8] strains within the major lineage and $2192.4-96.4 \%$ aa identity to human/feline G3P[9] strains. A third lineage included animal and animal22 like human G3 strains, likely derived from the canine host [De Grazia et al., 2007a]. A fourth 23 lineage exclusively included two Chinese G3 human rotaviruses isolated in 1986 and 1992. 24 Alignment of the deduced aa sequences of the antigenic variable regions (VRs) of VP7 [Estes and 
1 100; antigenic region A) a change at position 92 (Glu $\rightarrow$ Lys/Gln) was detected in one 1996 and in 2 two 2005 strains. An additional change, 91-Thr $\rightarrow$ Asn, was present in the VR5 of one of the two 32005 strains. Scattered aa mutations were also detected in the VRs 2, 3 and 4 of the VP7 of the 4 Italian G3P[8] strains (data not shown).

In the VP8* tree (data not shown), all the Italian G3P[8] rotaviruses clustered into the P[8]6 III lineage (95.1-100\% of aa identity), according to the four-lineages (I to IV) scheme described 7 previously [Wen et al., 1997; Suzuki et al., 1998]. In the same lineage there were also the G1P[8], 8 G4P [8] and G9P[8] strains circulating in Palermo in the same years.

Upon sequence analysis, all the 15 Italian strains were characterised as NSP4 E1 (B) 10 genotype. The nt and aa identities to the prototype E1 strain Wa ranged from 92.9 to $99.7 \%$ and 11 from 96.3 to $99.4 \%$, respectively. However, when the NSP4 aa sequences of the Italian G3P[8] 12 strains were analysed in detail (Figure 3), most of the 2003 isolates and the 2004 strain showed two 13 aa substitutions (131-His $\rightarrow$ Tyr and 141-Ile $\rightarrow$ Thr) within a region of the enterotoxin NSP4 with 14 demonstrated VP5*-binding activity (aa 114-147), whereas the oldest Italian G3P[8] strains did not. 15 In the same region, all the 2005 strains but one presented four or five aa substitutions (at position $16131,136,137,141$ and 145) with respect to the earlier Italian G3P[8] strains. Only a single 2003 17 strain, PA49/03/hu/G3P[8], displayed the same mutations as the 2005 strains, with the exception of 18 position 136 where a different change $(\mathrm{Thr} \rightarrow \mathrm{Val})$ was observed. In addition, the two most recent $19 \mathrm{VP}^{*}$-binding-region patterns were characterised by changes at position 111 and 137, that are 20 regarded as critical for antibody binding [Hyser et al., 2008], and by reversions at position 161 and 21169 to the original Wa-pattern within the VP6-binding region (aa 156-175). Most of the punctuate 22 mutations observed in the Italian strains occurred in the interspecies variable domain (aa 131-141), 23 that has been associated with species-specific antibody response [Yuan et al., 2004]. 


\section{Discussion}

In the infant population of Palermo between 1985 and 2004, G2P[4], G4P[8], and G9P[8]

3 strains varied in their distribution or completely disappeared for short or long periods of time, while

4 G1 strains tended to circulate continuously (Figure 1) [De Grazia et al., 2007b]. By converse, the 5 prevalence of G3P[8] strains has always been very low, with the exception of the years 2003 and 6 2005, when their prevalence increased up to 17\%. Previous studies have reported that G3 7 rotaviruses are intra-serotypically more heterogeneous than G1, G2 and G4 strains [Wen et al., 8 1997; Suzuki et al., 1998] and this is likely accounted for by their broad host range. However, by 9 phylogenetic analysis of G3 human and animal viruses, it is possible to identify species-specific 10 patterns of segregation that are helpful to track the origin of animal-like or animal/human 11 reassortant strains [Nishikawa et al., 1989; Martella et al., 2001; 2008]. Human G3 rotaviruses are 12 usually associated with P[8] VP4 specificity, and only sporadically with a P[9] type. While the VP7 13 gene of P[8] strains markedly differs from the VP7 gene of P[9] viruses [De Grazia et al., 2008], the 14 VP7 sequences of G3P[8] strains of global origin have revealed that common human G3P[8] form a 15 homogenous group [Martella et al., 2008]. In this study, comparative sequence analysis of Italian 16 G3P[8] strains collected over a large time span provided further evidence for a continuous 17 remarkable conservation in the VP7. By converse, analysis of G1, G2, G4 and G9 strains circulating 18 during the same period in Palermo, Italy, depicted a different situation, with the appearance and 19 disappearance of several lineages and/or variants over the years [Arista et al., 2004; 2005a; 2005b; 20 2006]. In particular, the analysis of G1P[8] strains, the predominant rotavirus strains in Italy and 21 worldwide, revealed an highly heterogeneous viral population exhibiting multiple amino acid 22 changes in the VP7 and VP4 antigenic regions involved in rotavirus neutralization compared to 23 those circulating in the previous years, thus suggesting mechanisms of antigenic escape [Arista et 24 al., 2006]. This model may not apply to viruses that circulate at very low frequency in a given population, such as G3P[8] rotaviruses. Interestingly, the Italian G3P[8] strains resembled in their VP7 and VP4 genes G3P[8] rotavirus strains detected recently in Japan, China, Russia and Ireland 
1 and reported to circulate at unusually high frequencies [Reidy et al., 2005; Phan et al., 2007; Trinh 2 et al., 2007]. Whether the increased activity of such G3P[8] strains relies on intrinsic features of the 3 VP7 and VP4, such as enhanced affinity for receptors or capsid stability, or on the properties of 4 other viral proteins, is unclear.

The NSP4 is a key protein involved in morphogenesis and pathogenesis of rotaviruses.

6 NSP4 acts as intracellular receptor for single-shelled particles and mediates viral assembly into 7 double shelled particles. NSP4 alone is able to induce diarrhea in experimental animals through a 8 Ca++-dependent signalling pathway and this activity has been mapped to the enterotoxigenic 9 domain (aa 114 to 135). Antibodies against NSP4, or against the toxic peptide, are able to prevent watery diarrhea, although the precise "in vivo" mechanisms of protection are unknown [Ball et al., 11 2005; Estes and Kapikian, 2007] and the NSP4 is currently a target for vaccine development [Yu 12 and Langridge, 2001; Choi et al., 2006]. The analysis of the NSP4 gene of the G3P[8] Italian 13 isolates allowed their inclusion into genotype E1 (B), a finding that was not unexpected, due to the 14 strength of the genetic linkage within each of the three human genogroups (Wa-, DS-1- and AU-115 like) [Bányai et al., 2009]. However, in the G3P[8] strains circulating in Palermo during 2003-2005, 16 multiple NSP4 amino acid substitutions were detected with respect to strains circulating in the 17 former years. These mutations affected the NSP4 region interacting with the VP4 (aa 114-147) 18 [Hyser et al., 2008] that includes the interspecies variable domain (aa 131-141) [Yuan et al., 2004] 19 and the sequence of the enterotoxic peptide (aa 114-135). Significant aa changes were observed also 20 at residues considered to be critical for antibody binding to NSP4 epitopes (residues 111 and 137) 21 [Hyser et al., 2008] and located within the VP6-binding region (residues 161 and 169) (Figure 3). 22 Whether these punctuate mutations may account for increased virus fitness, influenced by the 23 evolution of the NSP4-VP5* and/or NSP4-VP6 binding domains, or the appearance of NSP4 24 variants may facilitate the escape from acquired immunity is an intriguing possibility and surely deserves attention. The NSP4 aa pattern encountered in most of the 2005 Italian strains is not completely novel, since it has already been described in a G3P[8] strain collected in Leeds (UK) in 
11999 [Iturriza-Gòmara et al., 2003]. In addition, Brazilian G1P[8] and G9P[8] strains with NSP4 2 patterns resembling the 2003 and 2005 G3P[8] NSP4 patterns have been detected in 2001, 2003 and 32004 [Araujo et al., 2007; de Moraes Tavares et al., 2008]. In conclusion, analysis of G3P[8] strains detected in Palermo, Italy, over nearly 20-years of 5 uninterrupted rotavirus surveillance revealed that these rotavirus strains tended to be highly 6 conserved. The low heterogeneity of G3P[8] rotaviruses could be accounted for by the observed 7 low prevalence in the infantile population, preventing the onset of immune-pressure mechanisms. 8 The apparent increase in G3P[8] activity observed in Italy and in other countries worldwide remains 9 unclear. However, in this study some aa mutations in significant regions of the NSP4 protein 10 allowed to differentiate the old strains from the recent G3P[8] viruses, suggesting a possible 11 correlation with the G3P[8] peaks observed in 2003 and 2005. These findings may provide clues 12 for understanding of the mechanisms of evolution of rotavirus, which could be addressed in more 13 extensive investigations based on national and international surveillance programmes of rotavirus. 


\section{$\begin{array}{lll}3 & 1 & \text { Acknowledgments } \\ 4 & & \end{array}$}

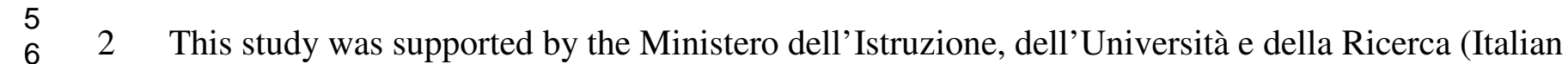

7

83 Ministry of Education, University and Reserch)(Fondi di Ateneo ex 60\%). 
1 Table I. Distribution and typing of the 59 G3 rotavirus strains circulating in Palermo in the 2 surveillance period 1985-2005.

\begin{tabular}{|c|c|c|c|c|c|c|}
\hline Year & $\begin{array}{c}\text { Total number of } \\
\text { G3 rotavirus } \\
\text { strains identified } \\
(\%) \\
\end{array}$ & $\begin{array}{l}\text { PAGE } \\
\text { e-type }\end{array}$ & VP6 SG & $\begin{array}{c}\text { G- } \\
\text { serotype }\end{array}$ & $\begin{array}{c}\mathrm{P} \\
\text { genotype }\end{array}$ & $\begin{array}{l}\text { Strains included in } \\
\text { this study }\end{array}$ \\
\hline 1988 & $1(1)$ & long & $\mathrm{I}$ & G3 & $\mathrm{P}[14]$ & - \\
\hline 1990 & $2(2.5)$ & long & II & G3 & $\mathrm{P}[8]$ & - \\
\hline 1993 & $1(1.2)$ & long & II & G3 & $\mathrm{P}[8]$ & PA85/93 \\
\hline 1994 & $1(0.9)$ & long & II & G3 & $\mathrm{P}[9]$ & PAF96/94* \\
\hline \multirow[t]{2}{*}{1996} & $6(6.1)$ & long & II & G3 & $\mathrm{P}[8]$ & PAH100/96, PA123/96 \\
\hline & 2 & long & I & G3 & $\mathrm{P}[9]$ & $\begin{array}{l}\text { PAH136/96*, } \\
\text { PAI58/96* }\end{array}$ \\
\hline \multirow[t]{3}{*}{1997} & $3(3.5) \quad 1$ & short & $\mathrm{I}$ & G3 & ND & - \\
\hline & 1 & long & II & G3 & $\mathrm{P}[8]$ & PAH101/97 \\
\hline & 1 & long & $\mathrm{I}$ & G3 & $\mathrm{P}[3]$ & PA260/97* \\
\hline 1998 & $1(3.3)$ & long & II & G3 & $\mathrm{P}[8]$ & - \\
\hline 2000 & $3(2.5)$ & long & II & G3 & $\mathrm{P}[8]$ & - \\
\hline 2002 & $1(2.6)$ & long & II & G3 & $\mathrm{P}[8]$ & - \\
\hline 2003 & $9(17)$ & long & II & G3 & $\mathrm{P}[8]$ & $\begin{array}{l}\text { PA21/03, PA45/03, } \\
\text { PA46/03, PA49/03 }\end{array}$ \\
\hline 2004 & $6(7.3)$ & long & II & G3 & $\mathrm{P}[8]$ & PA01/04 \\
\hline 2005 & $25(16.9)$ & long & II & G3 & $\mathrm{P}[8]$ & $\begin{array}{c}\text { PA21/05, PA95/05, } \\
\text { PA105/05, PA106/05, } \\
\text { PA110/05, PA116/05 }\end{array}$ \\
\hline Total & $59(3.7)$ & & & & & \\
\hline
\end{tabular}

3

$4 *$ These 4 strains having other than P[8] type have been described in details elsewhere [De Grazia et $5 \quad$ al., 2007a; 2008]. 
2 Araujo IT, Heinemann MB, Mascarenhas JD, Assis RM, Fialho AM, Leite JP. 2007. Molecular

Boom R, Sol CJ, Salimans MM, Jansen CL, Wertheim-van Dillen PM, van der Noordaa J. 1990. Rapid and simple method for purification of nucleic acids. J Clin Microbiol 28(3):495-503. 
1 Choi NW, Estes MK, Langridge WH. 2006. Mucosal immunization with a ricin toxin B subunitrotavirus NSP4 fusion protein stimulates a Th1 lymphocyte response. J Biotechnol 121(2):272-283.

Chouikha A, Fodha I, Noomen S, Bouzid L, Mastouri M, Peenze I, De Beer M, Dewar J, Geyer A, Sfar T, Gueddiche N, Messaadi F, Trabelsi A, Boujaafar N, Steele AD. 2007. Group A rotavirus strains circulating in the eastern center of Tunisia during a ten-year period (19952004). J Med Virol 79(7):1002-1008.

Ciarlet M, Liprandi F, Conner ME, Estes MK. 2000. Species specificity and interspecies relatedness of NSP4 genetic groups by comparative NSP4 sequence analyses of animal rotaviruses. Arch Virol 145(2):371-383.

Coulson BS, Fowler KJ, White JR, Cotton RG. 1987. Non-neutralizing monoclonal antibodies to a trypsin-sensitive site on the major glycoprotein of rotavirus which discriminate between virus serotypes. Arch Virol 93(3-4):199-211.

De Grazia S, Martella V, Giammanco GM, Iturriza-Gòmara M, Ramirez S, Cascio A, Colomba C, Arista S. 2007a. Canine-origin G3P[3] rotavirus strain in child with acute gastroenteritis. Emerg Infect Dis 13(7):1091-1093.

De Grazia S, Ramirez S, Giammanco GM, Colomba C, Martella V, Lo Biundo C, Mazzola R, Arista S. 2007b. Diversity of human rotaviruses detected in Sicily, Italy, over a 5-year period (2001-2005). Arch Virol 152:833-837.

De Grazia S, Giammanco GM, Martella V, Ramirez S, Colomba C, Cascio A, Arista S. 2008. Rare AU-1-like G3P[9] human rotaviruses with a Kun-like NSP4 gene detected in children with diarrhea in Italy. J Clin Microbiol 46(1):357-360.

de Moraes Tavares T, Elsner Diederichsen de Brito WM, Sousa Fiaccadori F, Leal de Freitas ER, Alves Parente J, Sucasas da Costa PS, Gimenes Giugliano L, Assis Andreasi MS, Almeida Soares CM, de Paula Cardoso DD. 2008. Molecular characterization of the NSP4 gene of 
human group A rotavirus samples from the West Central region of Brazil. Mem Inst Oswaldo Cruz 103(3):288-294.

Estes MK, Kapikian AZ. 2007. Rotaviruses. Knipe DM, Howley PM, editors. Philadelphia: Lippincott, Williams and Wilkins. 1917-1974 p.

Fang ZY, Wang B, Kilgore PE, Bresee JS, Zhang LJ, Sun LW, Du ZQ, Tang JY, Hou AC, Shen H, Song XB, Nyambat B, Hummelman E, Xu ZY, Glass RI. 2005. Sentinel hospital surveillance for rotavirus diarrhea in the People's Republic of China, August 2001-July 2003. J Infect Dis 192 Suppl 1:S94-99.

Gentsch JR, Glass RI, Woods P, Gouvea V, Gorziglia M, Flores J, Das BK, Bhan MK. 1992. Identification of group A rotavirus gene 4 types by polymerase chain reaction. J Clin Microbiol 30(6):1365-1373.

Gouvea V, Glass RI, Woods P, Taniguchi K, Clark HF, Forrester B, Fang ZY. 1990. Polymerase chain reaction amplification and typing of rotavirus nucleic acid from stool specimens. $\mathbf{J}$ Clin Microbiol 28(2):276-282.

Hyser JM, Zeng CQ, Beharry Z, Palzkill T, Estes MK. 2008. Epitope mapping and use of epitopespecific antisera to characterize the VP5* binding site in rotavirus SA11 NSP4. Virology 373(1):211-228.

Iturriza-Gòmara M, Green J, Brown DW, Desselberger U, Gray JJ. 1999. Comparison of specific and random priming in the reverse transcriptase polymerase chain reaction for genotyping group A rotaviruses. J Virol Methods 78(1-2):93-103.

Iturriza-Gòmara M, Wong C, Blome S, Desselberger U, Gray J. 2002. Molecular characterization of VP6 genes of human rotavirus isolates: correlation of genogroups with subgroups and evidence of independent segregation. J Virol 76(13):6596-6601.

Iturriza-Gòmara M, Anderton E, Kang G, Gallimore C, Phillips W, Desselberger U, Gray J. 2003. Evidence for genetic linkage between the gene segments encoding NSP4 and VP6 proteins in common and reassortant human rotavirus strains. J Clin Microbiol 41(8):3566-3573. 
1 Iturriza-Gòmara M, Kang G, Gray J. 2004. Rotavirus genotyping: keeping up with an evolving population of human rotaviruses. J Clin Virol 31(4):259-265.

3 Khamrin P, Maneekarn N, Peerakome S, Yagyu F, Okitsu S, Ushijima H. 2006. Molecular characterization of a rare G3P[3] human rotavirus reassortant strain reveals evidence for multiple human-animal interspecies transmissions. J Med Virol 78(7):986-994.

Kumar S, Tamura K, Nei M. 2004. MEGA3: Integrated software for Molecular Evolutionary Genetics Analysis and sequence alignment. Brief Bioinform 5(2):150-163.

Lee CN, Wang YL, Kao CL, Zao CL, Lee CY, Chen HN. 2000. NSP4 gene analysis of rotaviruses recovered from infected children with and without diarrhea. J Clin Microbiol 38(12):44714477.

Lo JY, Szeto KC, Tsang DN, Leung KH, Lim WW. 2005. Changing epidemiology of rotavirus Gtypes circulating in Hong Kong, China. J Med Virol 75(1):170-173.

Martella V, Pratelli A, Elia G, Decaro N, Tempesta M, Buonavoglia C. 2001. Isolation and genetic characterization of two G3P5A[3] canine rotavirus strains in Italy. J Virol Methods 96(1):43-49.

Martella V, Colombrita D, Lorusso E, Draghin E, Fiorentini S, De Grazia S, Banyai K, Ciarlet M, Caruso A, Buonavoglia C. 2008. Detection of a porcine-like rotavirus in a child with enteritis in Italy. J Clin Microbiol 46(10):3501-3507.

Matthijnssens J, Ciarlet M, Rahman M, Attoui H, Banyai K, Estes MK, Gentsch JR, IturrizaGomara M, Kirkwood CD, Martella V, Mertens PP, Nakagomi O, Patton JT, Ruggeri FM, Saif LJ, Santos N, Steyer A, Taniguchi K, Desselberger U, Van Ranst M. 2008. Recommendations for the classification of group A rotaviruses using all 11 genomic RNA segments. Arch Virol 153(8):1621-1629.

Nishikawa K, Hoshino Y, Taniguchi K, Green KY, Greenberg HB, Kapikian AZ, Chanock RM, Gorziglia M. 1989. Rotavirus VP7 neutralization epitopes of serotype 3 strains. Virology 171(2):503-515. 
1 Parashar UD, Gibson CJ, Bresse JS, Glass RI. 2006. Rotavirus and severe childhood diarrhea. Emerg Infect Dis 12(2):304-306.

3 Phan TG, Trinh QD, Khamrin P, Kaneshi K, Ueda Y, Nakaya S, Nishimura S, Sugita K, Nishimura T, Yamamoto A, Takanashi S, Yagyu F, Okitsu S, Ushijima H. 2007. Emergence of new variant rotavirus G3 among infants and children with acute gastroenteritis in Japan during 2003-2004. Clin Lab 53(1-2):41-48.

Reidy N, O'Halloran F, Fanning S, Cryan B, O'Shea H. 2005. Emergence of G3 and G9 rotavirus and increased incidence of mixed infections in the southern region of Ireland 2001-2004. J Med Virol 77(4):571-578.

Sanchez-Fauquier A, Montero V, Moreno S, Sole M, Colomina J, Iturriza-Gòmara M, Revilla A, Wilhelmi I, Gray J. 2006. Human rotavirus G9 and G3 as major cause of diarrhea in hospitalized children, Spain. Emerg Infect Dis 12(10):1536-1541.

Santos N, Hoshino Y. 2005. Global distribution of rotavirus serotypes/genotypes and its implication for the development and implementation of an effective rotavirus vaccine. Rev Med Virol 15(1):29-56.

Schumann T, Hotzel H, Otto P, Johne R. 2009. Evidence of interspecies transmission and reassortment among avian group A rotaviruses. Virology 386(2):334-343.

18 Solberg OD, Hasing ME, Trueba G, Eisenberg JN. 2009. Characterization of novel VP7, VP4, and VP6 genotypes of a previously untypeable group A rotavirus. Virology 385(1):58-67.

Suzuki Y, Gojobori T, Nakagomi O. 1998. Intragenic recombinations in rotaviruses. FEBS Lett 427(2):183-187.

Thompson JD, Higgins DG, Gibson TJ. 1994. CLUSTAL W: improving the sensitivity of progressive multiple sequence alignment through sequence weighting, position-specific gap penalties and weight matrix choice. Nucleic Acids Res 22(22):4673-4680.

Trinh QD, Pham NT, Nguyen TA, Phan TG, Khamrin P, Yan H, Hoang PL, Maneekarn N, Li Y, Kozlov V, Kozlov A, Okitsu S, Ushijima H. 2007. Amino acid substitutions in the VP7 
protein of human rotavirus G3 isolated in China, Russia, Thailand, and Vietnam during 2001-2004. J Med Virol 79(10):1611-1616.

Trojnar E, Otto P, Johne R. 2009. The first complete genome sequence of a chicken group A rotavirus indicates independent evolution of mammalian and avian strains. Virology 386(2):325-333.

Tsugawa T, Hoshino Y. 2008. Whole genome sequence and phylogenetic analyses reveal human rotavirus G3P[3] strains Ro1845 and HCR3A are examples of direct virion transmission of canine/feline rotaviruses to humans. Virology 380(2):344-353.

Wen L, Nakayama M, Yamanishi Y, Nishio O, Fang ZY, Nakagomi O, Araki K, Nishimura S, Hasegawa A, Muller WE, Ushijima H. 1997. Genetic variation in the VP7 gene of human rotavirus serotype 3 (G3 type) isolated in China and Japan. Arch Virol 142(7):1481-1489.

Yoshinaga M, Phan TG, Nguyen TA, Yan H, Yagyu F, Okitsu S, Muller WE, Ushijima H. 2006. Changing distribution of group A rotavirus G-types and genetic analysis of G9 circulating in Japan. Arch Virol 151(1):183-192.

Yu J, Langridge WH. 2001. A plant-based multicomponent vaccine protects mice from enteric diseases. Nat Biotechnol 19(6):548-552.

Yuan L, Honma S, Ishida S, Yan XY, Kapikian AZ, Hoshino Y. 2004. Species-specific but not genotype-specific primary and secondary isotype-specific NSP4 antibody responses in gnotobiotic calves and piglets infected with homologous host bovine (NSP4[A]) or porcine (NSP4[B]) rotavirus. Virology 330(1):92-104.

Zhou Y, Li L, Okitsu S, Maneekarn N, Ushijima H. 2003. Distribution of human rotaviruses, especially G9 strains, in Japan from 1996 to 2000. Microbiol Immunol 47(8):591-599. 
1 Figure Legends

2

3 Figure 1. Percent temporal distribution of G1-G4 and G9 types of rotavirus strains circulating in

4 Palermo, Italy, from 1985 to 2005.

5

6 Figure 2. Phylogenetic analysis of nucleotide sequences of the VP7 gene of G3 strains. Italian

$7 \mathrm{G} 3 \mathrm{P}[8]$ strains are highlighted in boxes, G3P[9] and G3P[3] are in bold. The origin of rotavirus

8 strains is indicated as follows: hu=human; $\mathrm{ca}=$ canine. The tree was generated based on the

9 neighbor-joining method using ClustalW program. Bootstrap values above 50\%, estimated with

101,000 pseudoreplicate data sets, are indicated at each node.

12 Figure 3. Deduced amino acid sequences of the NSP4 protein of Italian G3P[8] strains collected 13 during the study period. The region involved in the binding to VP5* (aa 114-147) is indicated in 14 light grey. The VP6-binding region (aa 156-175) is marked in dark gray. The interspecies variable 15 domain (aa 131-141) is indicated by the thick dotted area. The sequence of the enterotoxic peptide 16 (aa 114-135) corresponds to the thin dotted area. Critical residues for antibodies recognition are 17 highlighted $(\boldsymbol{\nabla})$. Conserved amino acid residues are indicated by dots. Wa/hu/G1P[8] is included as 18 the NSP4 genotype E1 rotavirus standard. 